\title{
sciendo
}

CIVIL AND ENVIRONMENTAL ENGINEERING REPORTS

E-ISSN 2450-8594

CEER 2020; 30 (2): 0055-0064

DOI:10.2478/ceer-2020-0019

Original Research Article

\section{EXPRESSION OF GLUED LAMINATED TIMBER IN LONG SPANS STRUCTURES ASSOCIATED WITH ITS NATURAL ORIGIN}

\author{
Alicja MACIEJKO 1 \\ Institute of Architecture and Urban Planning, University of Zielona Góra
}

\begin{abstract}
The article presents an analysis of the possibilities of shaping long - span structures using the expressive force of glued laminated timber related to its natural origin. Changes that arose in the 20th century and at the beginning of the 21 st century under the influence of new technological possibilities in the field of woodworking, as well as radical changes in the doctrine of environmental protection, also changed the position of timber as an innovative construction material. Recent developments are considered groundbreaking. Timber is used both in large span structures as well as for the construction of multi-storey buildings, which opens the door for shaping new architectural forms. The principles of girder modelling and features related to timber symbolism were presented.
\end{abstract}

Keywords: glued laminated timber, glulam, long-spans structures, large span constructions, structural design, conceptual design, symbolism of wood

\section{INTRODUCTION}

Structures made of glued laminated timber have specific features related to the natural origin of the raw material. In simplified terms, it can be assumed that they use nature in two ways. On the one hand, by using natural raw materials

\footnotetext{
${ }^{1}$ Corresponding author: University of Zielona Góra, Institute of Architecture and Urban Planning, a.maciejko@aiu.uz.zgora.pl, telephone:+48 683282593
} 
and designing architecture in the ecological trend, on the other hand, by imitating shapes found in nature in construction forms.

Shaping the structures of large spans at the conceptual stage has a large share in creative activities related to the search for new spatial forms, hence the close cooperation of the structural engineer and the architect is required, whom in such dynamic solutions will emphasize the aesthetics of expression and the beauty of the material. Forms of buildings with large spans made of glued timber can be sculptural, dynamic, symbolic and surprising, as well as universal, rhythmic, "disappearing", fluid and variable or referring to solutions occurring in nature. Despite the different shaping of the structure, the spatial structure is important and exposed here.

In the case of objects with large spans, structural solutions are inextricably linked to the technology of the construction material used. They should be lightweight structures shaped in such a way that the load-bearing structure, which is the element exposed in the interiors, is structurally optimal, economical and at the same time visually attractive.

Structures made of glued timber can be classified as so-called lightweight structures. According to Schlaich Błąd! Nie można odnaleźć źródła odwołania., "Such structures are defined as constructions in which the $\mathrm{p} / \mathrm{g}$ (useful load "p" is "transferred" by the dead weight "g") and "stiffness/g" indicators are high. The less important the limitation of deformations is, the greater the chances of lightweight structures are, since large-span roofing works mainly for stretching. The economic advantage of tensile structures with single or double curvature is however limited by expensive anchor systems and the creation of horizontal force transfer systems. The output is "self-balancing" structures, but they require a circular or elliptical plan, which limits their shapes. This is a typical example of the subjective, personal nature of the conceptual design process. Absolute freedom comes at a price, and there is an award for discipline Błąd! Nie można odnaleźć źródła odwołania.

Glued timber, which is one of the lightest construction materials, is also the only fully renewable material, easy to obtain and process. The production process on the raw material for final incorporation does not radically change the characteristics of timber (it still has the characteristics of natural material), while it significantly increases its structural properties. Despite many years of use, they are still considered future-proof. Glued timber was considered a material of the future as early as the 1960s. In 1964, German scientist F. Kollman published the article "Timber as a building material of the future" in the Holzzentralblatt magazine Błąd! Nie można odnaleźć źródła odwołania. but specialist knowledge that these systems are durable, technically refined and safe had not yet been fully transferred to the implementation practice. While basic construction materials, e.g. steel, are widespread in the construction of large 
spans for obvious reasons, glued laminated timber structures are still characterized as experimental, and its properties and behaviour during operation are less recognized.

\section{MATERIAL SYMBOLIC}

The expression of architecture depends very much on the construction material used, which, as in the case of timber, evokes additional symbolic meanings. Glued laminated timber can imitate soft, organic shapes thanks to the gluing technology of arch elements formed in various sizes and radii. Imitating the shapes of nature and, at the same time, emphasizing the ecological qualities of such constructions, are reflected in many modern buildings.

The qualities of timber, its shapes, colour, artistry of processing and modelling have long been used to create "unusual" objects. These objects were associated with symbolic, immaterial, almost magical values, such as travelling into the unknown, overcoming the force of gravity, overcoming water spaces. The property of plastic shaping has long been associated with timber. Now, using the same property of modelling that "extracts the soul of timber", we can form largescale space, construct buildings and their load-bearing systems. Thus, new, unusual forms are created, and a new aesthetics of architectural objects is emerging. Thomas Herzog talks about "instrument buildings that the user will play"Błąd! Nie można odnaleźć źródła odwołania..Herzog refers here to Hall 26 at the Hanover Fair, but the building that directly implements the postulate of the architecture of the instrument is the Sibeiustalo concert hall in Lahti Błąd! Nie można odnaleźć źródła odwołania. entirely made of timber, which was established as a continuation of the Finnish national tradition and in order to use the excellent properties of timber, including acoustic. The choice of material gives the opportunity to show its nature, character and symbolism. The materials bring symbolic meanings, the surfaces reflect the quality of the building's duration over time. The stones speak of distant geological origin, are durable and are a natural symbol of longevity. Bricks bring to mind earth, fire, and medieval construction traditions. Wood speaks of two different forms of duration. Its first life as a growing, living tree and the second, a work done by human hand. Buildings that use glued laminated timber structures are human friendly because they have good acoustics, microclimate and insulating properties, structural elements do not have to be hidden and encapsulated, they resist moisture changes and have beneficial psychophysical effects.

The choice of natural construction material, which is glued laminated timber, gives tips on moving within a certain area, which results from its technological capabilities and natural properties that are read "intuitively". Wood in its original form of a tree, trunk and branches, has a very characteristic shape that evokes 
the symbolism of natural construction, longevity, strength and high endurance. Like the forest, the load-bearing elements are combined into spatial arrangements, giving different static functions to trunks, limbs, branches and leaves. Although only nature can create a tree, human creativity allows the symbol of the tree to be transferred into the architecture area in its character and manner of operation. The logic of the forest, its complicated and at the same time orderly structure, mood, longevity and endurance, as well as ambiguous symbolism as a "roof" - shelter from rain, wind and sun, detachment from space of the earth, will still be an inspiration for new searches for construction forms. Intuitively, therefore, in load-bearing structures, a limb are used as a beam, a trunk as a column, its plasticity of wood is intuitively used and objects are formed into curvilinear systems. However, the spontaneity and uniqueness of systems and shapes, especially in the "forest" space, perceived as unorganised, are usually unprofitable in construction. Forms directly copied from nature may seem random.

\section{DESIGN EXPERIMENTS: NATURE - STATICS - SCULPTURE FORMS}

The choice of construction material is an opportunity to give architecture the intended aesthetic features by using spatial effects that can be built with the given material. The 20th century and the beginning of the 21 st century are years of fascination with construction systems and a new approach to dynamic creation of architectural forms, which is confirmed by the numerous projects of large spans. In these objects, the dynamics of forms and the associated expression of forces seems to be particularly justified, because the possibilities of covering them with simple beam systems are significantly exceeded. Designers use the structure for architectural effects, the construction of forms serves to show the distribution of static forces and the use of material and technical capabilities. Achievements of architects and engineers such as, among others: Saarinen, Utzon, Calatrava, Nervi, Fuller, Frei Otto, Aalto, Piano, Ando, Rogers, Tschumi, Foster, Samyn Ito, Isozaki, Grimshaw, Nowicki, Perrault, Nouvell and others show that the structure, previously hidden under a decorative facade, in the 20th century, became one of the basic means of expression. The specificity of objects with large spans in prestigious buildings allows the use of structural systems that, through their large scale and ability to reveal "expression of forces", create attractive architectural forms."Buildings with large spans, including tall buildings, form a group of specific objects, usually of great importance in the civilizational development of individual societies." (...) In terms of aesthetics, the objects of this group are characterized by the use of simple and coherent architectural forms with legible elements of symmetry in 
whole or in parts of such an assumption" Błąd! Nie można odnaleźć źródła odwołania..

In addition to technical conditions in the construction of large spans, there are symbolic and prestigious relationships that cause that often the most economical solutions are abandoned in favour of recognizable and unique architecture in which the structure is used for a distinct effect. These are very often buildings with unprecedented systems, ideas or innovative static systems - "sculptures and symbols" and organic objects, imitating natural forms. The reference to the world of nature and copying its solutions is visible in many projects, the way of constructing forms is to illustrate and symbolize forces dormant in nature. Innovative solutions and experiments affect the outer casing and structural structure to the greatest extent.

Strong relationships with nature, in addition to the very origin of the raw material, is the unique ability of glued timber to create plastic forms. The origin of the wood and its properties inspire designers to imitate the shapes found in nature. In contrast, processing technology and design allow for economical use of material capabilities to give the designed forms of construction geometric cleanliness and appropriate static work. The way of receiving curvilinear systems in perspective and the fact that they are covered with plastic materials such as fabrics or membranes make these systems seem to be spatially multilayered, non-geometrical, with high expression, which is associated with modernity, even if they are determined by simple geometric principles. The attractiveness of seemingly complex curvilinear forms (hanging and two-curved grid systems) is dictated by the fact that under the influence of the development of technical possibilities, soft forms of large span objects imitating organic forms were obtained for the first time. The impact of nature on engineering and architecture is enormous, nature symbols are still invariably used as structural elements. The tree, trunk, branches, leaves, stems, forest - as a structure of related elements, shells, flower petals, shells of crustaceans, turtles and battleships, vertebrate skeletons as an inspiration for roof structure design.

Designing architecture modelled on the human or animal body most often concerns the skeleton, which is the structure that maintains the entire biological system. The connections between architecture and the skeletal system seem too obvious. In architecture, the skeleton is imitated most often in the way it works or literally, e.g. in Casa Batlo in Barcelona by Antonio Gaudi, where the spine, almost literally copied, serves as a staircase barrier. The spine also became the subject of the experiment of the designer Frei Otto. He built a movable column form with separate elements connected by a steel rope. Frei Otto believed that this is how tall buildings can be constructed Błąd! Nie można odnaleźć źródła odwołania..Skeletal architecture is most often defined in a beam-column structure, although in the construction of organisms there are no bones 
connected into rectangular systems. Here, the structural skeleton merely copies the way the biological system works - separating the support from filling as separate tissues. Natural constructions of animal organisms were also studied and used by Liga Nervi, B. Fuller, I. Makowecz and today S. Calatrava, R. Piano and others from their design ideas.

On the one hand, nature is perceived as a source of inspiration for the construction of architectural forms and an "imitated master"Błąd! Nie można odnaleźć źródła odwołania., on the other hand, its infallibility is denied, by presenting the achievements of civilization that surpassed it, or those that, although irreplaceable in the modern world, do not have their equivalent or even a prototype in nature. According to Sławińska, "the use of the laws of physics for deliberately intended purposes and the blind, governed by the same laws of evolution often leads to similar results"Błąd! Nie można odnaleźć źródła odwołania..Thus, both nature inspirations as well as mathematical and static analyses can lead to the creation of new construction systems. Examples are hyperbolic paraboloid, rectangular curve, having no counterparts in nature, and disc constructions. Inspirations of nature, in a manner characteristic of man, are never free from being marked with "culture". Nature is processed by a logical factor that organizes freedom and chaos.

\section{MODELLING OF GLUED LAMINATED TIMBER CONSTRUCTION ELEMENTS}

Structures made of glued laminated timber, modelled on a tree symbol, but also due to the conditions of the physical structure of wood and its mechanical properties arise from the connection of load-bearing elements of straight and arched structures (main and complementary).The basic elements are: a simple element with a rectangular cross-section and an arch element in one plane (vertical) and a rectangular cross-section. Elements with a round cross-section are used as trunks as supports. The joining of components is done by means of various connectors, usually steel ones. In the case of glued timber it is possible to obtain permanent glued joints - wedge-shaped, most often in frame systems implemented using glued knots or embedded sheets. However, typical for wooden constructions is articulated joining of elements. Soft and organic systems are most often arches, domes, single-curved and two-curved spatial grids, hanging coverings. However, it is worth emphasizing that glued timber in such systems, despite the fact that as a material is able to absorb both compression and stretching, always works with steel elements. Therefore, the basic problem in the production of load-bearing glued laminated timber is taking into account the limited possibility of shaping it. Forming arches is one-plane and possibly only in the plane transverse to the slats, i.e. in the plane of the 
manufactured element. Obtaining curves from the plane of the produced element is impossible to achieve during the traditional gluing process. A curved element from the plane is obtained by joining - gluing vertically - several previously manufactured arch beams with smaller cross-sections and may cause a reduction in the cross-section load capacity. Production of curved elements in two or more planes is currently possible, but it is a technically complicated and expensive process. An example of the double curvature of the girder along with the variable cross-section of the elements are the spans of the Leonardo Da Vinci Bridge in Norway. However, bending of the elements in two planes was not used here, because it is hindered by the construction of the timber, which generates, in a natural way, the ease of giving deformation from bending along the fibres. The girder was created as a connection by means of glue and WT and SFS fasteners, several arched beams and then, by machining (cutting) the second plane to the target arch form. The reference to the organic forms of the limbs of the trees (branches), which bend softly in several planes, is therefore done using complicated methods.

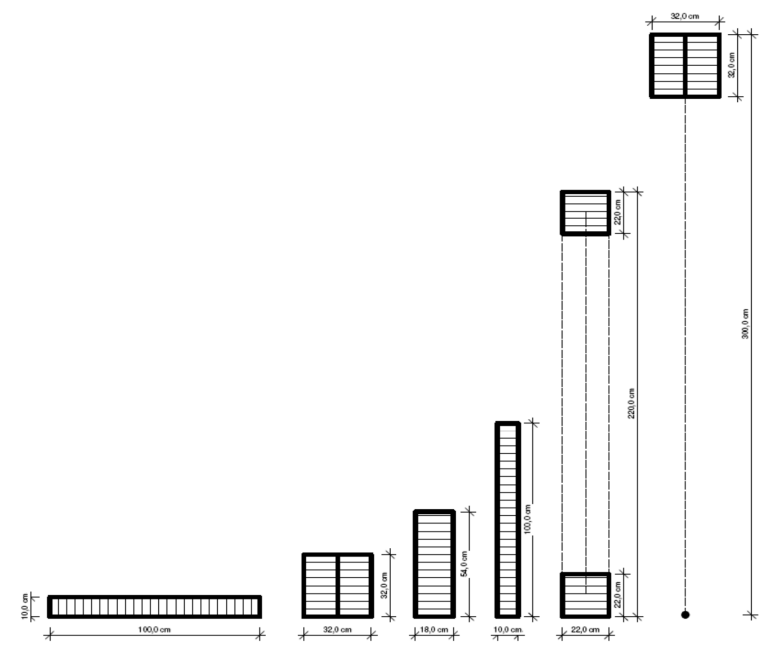

Fig. 1.Shaping cross-sections of load-bearing beams. The cross-sectional areas of the total load-bearing elements are approximately $10,000 \mathrm{~cm} 2$. The shape of the girders allows for a span of 1 to $100 \mathrm{~m}$ with the use of a steel cable, Błąd! Nie można odnaleźć źródła odwołania.

The vast majority of glued timber construction systems consists of straight and arched beams (with fixed or variable radii), rectangular cross-sections or modelled by mechanical machining using a CNC numerically controlled set, and various connectors, mechanical, steel or glue, integrating individual structural elements and other elements of other materials, e.g. steel bowstring and tie rods. 
Modelling of glued timber shapes is done by gluing into target forms, straight or curvilinear. The plastic property of relatively thin (up to $40 \mathrm{~mm}$ thick) planed boards (slats) used for gluing structural elements allows for giving arches in the plane of the element to a limited extent. The possible bending radius is $600 \mathrm{~cm}$. For smaller bending radii, thinner sawn timber is used accordingly. Elements are placed in presses. The second stage of forming elements is machining, i.e. length machining, cutting slopes or curves, cutting the seats into adjoining elements, etc. Machining is carried out using hand saws or specialized CNC numerically controlled sets, which are used for smaller dimensions due to the limited dimensions of the machines. Even systems with seemingly free forms consist of straight and arched beams shaped in various spatial configurations.

\section{SUMMARY}

Contemporary design trends tend to experiment with form and construction materials, especially in prestigious buildings, hence so many implementations with individual solutions. The increase in the spans and the pursuit of everincreasing lightness results in the search for innovative solutions using the loadbearing properties of various construction materials, composite and hybrid structures, e.g. wood-steel. This is also beneficial for aesthetic reasons. A full girder made of glued timber with a span of over 40 meters will have an average height of over 2 meters, but when using, for example, supporting steel elements, this height will be significantly reduced. This must be anticipated when planning the interior. In fact, although structures look free and organic, girders and other structural elements are subject to significant restrictions in shaping sections and forms. It is, first and foremost, a limitation in curvature. Modelling of glued wood beams takes place according to the following rules:

1. The structural elements are homogeneous and full.

2. Curving is possible in the vertical plane of the element.

3. Shaping the cross-section with different strength classes is done by varying the strength classes of sawn timber ( $\mathrm{C}$ sections - mixed, and $\mathrm{H}$ homogeneous) according to standard guidelines,

4. Beams are glued in one section to a length of up to $65 \mathrm{~m}$, depending on the type of press in the production plant. The slats butt joints are made in the form of wedge joints. Recommendations for the production of joints and the arrangement in individual slats of the cross section along the length of the element are covered by the standard.

5. To achieve proper work of the shear element, it is required to leave the bottom supporting girders without cutting.

6. Various shapes of straight beams in the longitudinal view can only be obtained by modelling (cutting) the upper lamellas . It is unacceptable to cut 
the bottom lamellas due to the possibility of splitting the timber along the fibres.

7. The effect of the variable height of the bottom band can only be achieved by using arched elements, where the bottom band always consists of full slats.

8. It is possible to perforate full girders after calculations, but it is energyconsuming, as is surface grinding and cross-section modelling (cutting).

9. It is possible to increase the load capacity of the girders by factory gluing steel inserts or composite material inserts (carbon, glass or aramid) in the cross-section.

10. The lattice girders are composed of straight or arched elements and joined elements, e.g. built-in steel sheets. The elements are assembled at the factory or, after analysing the transport possibilities, in whole or in part at the construction site. Seats, due to the high responsibility of the nodes, should always be made at the factory.

11. Individual elements from glued timber are cut to desired lengths. However, you can leave the tips uncut, then they are processed on the construction site.

Perspectives for new possibilities of shaping architectural forms with large spans of glued timber are based, above all, on the current load-bearing properties of the reinforced cross-section cooperating with steel and composite elements in innovative double-curved systems, as well as on high-quality architectural works using glued timber construction, in aesthetic, social, economic and ecological terms. Displaying the timber in the structure allows the created architectural forms to achieve expressive and aesthetic effects that go far beyond the purely technical and structural nature.

\section{REFERENCES}

1. Woodforgood, Sibelius Hall, Lahti, Finland.

2. Feuerstein, G 2002. Biomorfic Architecture. Menschen- und Tiergestalten in der Architektur. Stuttgart/London: Edition Axel Menges.

3. Kairi, M 2001. Screw glued wooden structures in Sibelius Hall. Lahti, Finland: IABSE Conference Innovative Wooden Structures and Bridges.

4. Kołakowski, M 1997. Architektura jak instrument. Warszawa: Architektura i biznes 9.

5. Maciejko, A 2011. Analiza przydatności konstrukcji z drewna klejonego do konstruowania form architektury wspótczesnej, rozprawa doktorska. Wydział Architektury Politechniki Wrocławskiej.

6. Mielczarek, Z 1994. Budownictwo drewniane Warszawa: Arkady. 
7. Natterer, J, Herzog, T and Volz, M 1991. Holzbau Atlas Zwei. DETAIL, Institut fuer internationale Architektur-Dokumentation GmbH \& Co. KG.

8. Rębielak, J 1992. Struktury przestrzenne o dużych rozpiętościach. Wrocław. Wydawnictwo Politechniki Wrocławskiej.

9. Schlaich, J 2007. Koncepcyjne projektowanie lekkich konstrukcji. Inżynieria i Budownictwo 3.

10. Sławińska, J 1997. Ekspresja sit w nowoczesnej architekturze. Warszawa: Arkady.

11. Zalewski, W 2000. Moc i lekkość - muzy projektanta konstrukcji. Architektura-Murator, 11.

Editor received the manuscript: 18.12.2019 